\title{
Collaborative Approach for Teaching Chemical Process Design
}

\author{
Michel F. Couturier and Guida Bendrich \\ University of New Brunswick \\ cout@unb.ca, bendrich@unb.ca
}

\begin{abstract}
A collaborative approach has been successfully used to teach the senior process design course in the Chemical Engineering program at UNB since 2010. Every design project in the course is sponsored by an outside client. Two teams of four or five students are assigned to each project. The teams work independently and are co-mentored by a faculty member and a practicing engineer. This collaborative approach brings engineering practice in the classroom while keeping faculty members in control of academic requirements. Eight evenly-spaced milestones pace students and co-mentors by defining the tasks that need to be accomplished, by setting the marking scheme for the deliverables and by providing a framework for the progressive assembly of a high-quality final report. Our approach has increased the number of faculty members interested in design activities and allows students to contribute to the local economy while becoming proficient in engineering design. Comments received from students, clients and co-mentors have been highly positive.
\end{abstract}

Keywords: Process design, industry-academia collaboration, design team mentoring, design milestones.

\section{INTRODUCTION}

The senior design course prepares engineering students for their future career by helping them make the transition from solving well-posed problems in a specific subject to solving open-ended problems [1]. During the transition, students develop confidence in making decisions and come to realize that solutions to real world problems require both integration of prior knowledge and creativity [2]. A successful senior design course is one of the most rewarding courses in the curriculum for student and teacher [3].

The success of the senior design course depends greatly on the nature of the problems suggested to the students. Problems recycled from previous offerings of the course or case studies found in textbooks fail to inspire students. We find that engineering students are motivated by the dual desires of solving problems and making the world better. They consequently show more enthusiasm in the senior design course when working on problems provided by outside clients. Many engineering professors are however apprehensive to supervise clientbased projects. Although design is a crucial element of the innovation process [4] and often said to be the essence of engineering [5], it was not a major focus of engineering education in North America between the years 1960 and 2000 [6]. During this period, Canadian universities focussed primarily on teaching engineering science subjects and the task of providing design training to young engineers was left largely to companies. As a result, most engineering professors currently teaching at Canadian universities have received little training in design unless they worked in industry at one point in their career.

This paper describes a collaborative approach for teaching design which addresses the above issues. The approach has been used in the Chemical Engineering Department at the University of New Brunswick since 2010 to teach the capstone design course ChE 4225 Chemical Plant Design. Design projects undertaken in the course are sponsored by outside clients and every student team is co-mentored by a faculty member and a practicing engineer. This collaborative approach for teaching design benefits all parties. It motivates students by exposing them to the complexity and excitement of dealing with real world problems; it helps local companies obtain innovative design solutions; it brings engineering practice in the classroom; and it makes the participation of faculty members in design activities less daunting. Faculty members remain in control of the academic requirements while learning about best practices used in industry from the industrial co-mentors. Funding for the industrial co-mentors is provided by the NSERC-UNB Chair for Collaborative Engineering Design Education held by one of the co-authors (M. Couturier). Although the model presented in this paper is described in the context of our process design course, it is adaptable to other engineering disciplines.

\section{COURSE STRUCTURE}

\subsection{Course Objectives}

ChE 4225 is a chemical process design course which runs from September to April every academic year. It is 
taken by chemical engineering students in their senior undergraduate year and is the last of a four-course sequence on design. To meet course requirements, students must complete the conceptual design of a chemical plant. They start by determining the needs of the client and conducting a thorough review of the technical and patent literature to identify existing technologies for manufacturing the product(s) of interest. Then, for the most promising process, a base-case design is developed, including a detailed process flow sheet with mass and energy balances, separation train, and heat integration scheme. Equipment is then sized, estimates of capital and operating costs are obtained, a profitability analysis is completed, and a final optimization is carried out. Students must make effective use of modern engineering tools and methods, and their solution must meet a broad range of constraints including health and safety, sustainable development and environmental stewardship. Students are also expected to integrate knowledge acquired in previous courses and continue developing professional skills such as teamwork, project management, oral presentations, and report writing.

\subsection{Client-based Projects}

Each summer we seek suitable design projects by contacting local companies and governments. The work is done at no cost to the clients but we ask that each client meet with the students at least four times during the year: 1) in September to define the scope of the work with the students, 2) in November to evaluate the solution proposed by the students, 3) in February to evaluate the final design proposed by the students, and 4) in early April to listen to the final presentation of the students.

Two teams of four or five students are assigned to each project to avoid client disappointment if one team runs into academic difficulties. We let the students choose their teammates and the project on which they prefer to work. Brief project descriptions are provided to the students at the start of the year to guide their selection. A sample project description is provided in Table 1 and the projects completed in 2012-2013 are listed in Table 2.

Table 1: Sample project description given to students at the beginning of the year.

\begin{tabular}{|l|l|}
\hline Design Project & \multicolumn{1}{|c|}{ Description } \\
\hline $\begin{array}{l}\text { Power } \\
\text { generation plant }\end{array}$ & $\begin{array}{l}\text { The price of natural gas has dropped } \\
\text { using natural } \\
\text { gas (client: NB } \\
\text { has become an attractive fuel for power } \\
\text { Power) }\end{array}$ \\
$\begin{array}{l}\text { generation. Determine the economic } \\
\text { viability of installing a 400 MWe } \\
\text { power generation unit next to the } \\
\text { existing Coleson Cove power plant. }\end{array}$ \\
\hline
\end{tabular}

Table 2: Design projects completed in 2012-2013.

\begin{tabular}{|c|c|}
\hline Design Project & Client \\
\hline $\begin{array}{l}\text { 1. Power generation plant } \\
\text { using natural gas }\end{array}$ & NB Power \\
\hline $\begin{array}{l}\text { 2. Conversion of the waste } \\
\text { streams of a brewery into } \\
\text { valuable products }\end{array}$ & Molson Coors \\
\hline $\begin{array}{l}\text { 3. Conversion of lobster } \\
\text { shells into valuable } \\
\text { products }\end{array}$ & $\begin{array}{l}\text { Village Bay Sea } \\
\text { Products }\end{array}$ \\
\hline $\begin{array}{l}\text { 4. Alkylation of refinery } \\
\text { propylene }\end{array}$ & Irving Oil \\
\hline $\begin{array}{l}\text { 5. Production of valuable } \\
\text { chemicals from kraft- } \\
\text { pulping liquor }\end{array}$ & AV Nackawic \\
\hline
\end{tabular}

\subsection{Mentoring of Design Teams}

The two teams assigned to each project work independently and are co-supervised by a faculty member and a practicing design engineer. The industrial comentors are the primary coaches of the students and are drawn from the large pool of design engineers who work for engineering consulting firms in the Fredericton region. The faculty co-mentors ensure that course requirements are met, that the students are being sufficiently challenged and are using all the tools available to them. Co-mentors are expected to meet with each team under their responsibility for one hour every week and to provide written feedback on the progress reports submitted periodically by the students. The meeting with the industrial co-mentor is normally in the evening or weekend whereas the meeting with the faculty co-mentor is normally on a weekday.

Two course coordinators look after the overall management of the course. The coordinators are responsible for finding the clients, inviting guest speakers for the weekly lectures and setting the milestones that all teams must meet.

\subsection{Milestones}

Guidance needs to be provided to the co-mentors and students to ensure that all groups are progressing at the same rate and are evaluated against the same criteria. We pace the students by setting eight evenly-spaced milestones (four per term) that all teams must complete. Each milestone contains a set of tasks that apply to all projects. We review the methods that should be used to complete the tasks in the weekly lectures.

The students have three weeks to complete each milestone and must summarize their work in a new section of their design report. The due date for the milestones is defined by the course schedule given to the students at the 
Table 3: Course schedule 2012-2013

\begin{tabular}{|c|c|c|}
\hline \multicolumn{2}{|l|}{ Milestones } & Due Date \\
\hline \multicolumn{2}{|l|}{ 1. Project scope } & Sept. 30, 2012 \\
\hline \multicolumn{2}{|l|}{ 2. Literature review } & Oct. 21,2012 \\
\hline \multicolumn{2}{|l|}{ 3. Base case design } & Nov. 11, 2012 \\
\hline \multicolumn{2}{|c|}{ 4. PFD \& preliminary mass balance } & Dec. 2, 2012 \\
\hline \multicolumn{2}{|c|}{ 5. Completion of mass and energy } & Jan. 27, 2013 \\
\hline \multicolumn{2}{|c|}{ 6. Equipment sizing and cost estimates } & Feb. 17, 2013 \\
\hline \multicolumn{2}{|c|}{ 7. Economic and sensitivity analyses } & March 17, 2013 \\
\hline \multicolumn{2}{|c|}{ 8. Final report } & April 7, 2013 \\
\hline Oral Presentations & & Date \\
\hline 1. Client meeting I & Sept. & $0-21,2012$ \\
\hline 2. Client meeting II & Nov. 1 & $-30,2012$ \\
\hline 3. Client meeting III & Feb. 18 & - March 1, 2013 \\
\hline 4. Final presentation & April 1 &, 2013 \\
\hline
\end{tabular}

beginning of the year (Table 3). The outline for each milestone summarizes the tasks and provides the marking scheme that will be used by the co-mentors to evaluate the deliverables. An example is provided in Table 4.

Each written submission is first evaluated by the industrial co-mentor and then reviewed by the faculty comentor. The marked submission containing the written comments of both co-mentors is returned to the students within two weeks. The students are expected to make the corrections suggested by the co-mentors before their next written submission.

Table 4: Typical milestone: Milestone 5

\begin{tabular}{|c|c|}
\hline ChE 4225 Assignment Outline & $\begin{array}{l}\text { Due date: January } 27 \\
2013\end{array}$ \\
\hline $\begin{array}{l}\text { Milestone } 5 \text { - Completion of Mass \& } \\
\text { Energy Balances }\end{array}$ & \\
\hline \multicolumn{2}{|c|}{$\begin{array}{l}\text { In this milestone, you will finalize the mass and energy } \\
\text { balances for your process. You must also update your Process } \\
\text { Flow Diagram (PFD) to reflect the results of this milestone. } \\
\text { This work forms an integral part of the final design report. } \\
\text { The work must be completed as a group and one submission } \\
\text { per group must be issued for marking. The group leader will } \\
\text { assign specific tasks to the group members. The following } \\
\text { tasks need to be accomplished for Milestone 5: }\end{array}$} \\
\hline
\end{tabular}

\begin{tabular}{|l|c|l|l|}
\hline $\begin{array}{c}\text { Task } \\
\text { Description }\end{array}$ & $\begin{array}{c}\text { Mark } \\
\text { Distribution } \\
(\%)\end{array}$ & Guidelines/Comments & Mark \\
\hline $\begin{array}{l}\text { 5.1 Report } \\
\text { Revisions }\end{array}$ & $\mathbf{1 0}$ & $\begin{array}{l}\text { Combine this milestone } \\
\text { and the corrected previous } \\
\text { milestone in one document } \\
\text { (electronic and paper } \\
\text { format required) } \\
\text { Submit the original } \\
\text { marked version of the } \\
\text { previous milestone as a } \\
\text { separate document in } \\
\text { paper format only! }\end{array}$ & \\
& & Report: Grammar, & \\
\hline 5.2 Report & $\mathbf{1 0}$ & & \\
\hline
\end{tabular}

\begin{tabular}{|c|c|c|}
\hline Format & & spelling, formatting \\
\hline $\begin{array}{l}.3 \text { Energy } \\
\text { Balances }\end{array}$ & 30 & $\begin{array}{l}\text { Complete all energy } \\
\text { balances and clearly } \\
\text { describe your calculations } \\
\text { in the appendix of your } \\
\text { report. Enter appropriate } \\
\text { results in the stream } \\
\text { summary table of your } \\
\text { PFD. } \\
\text { State your assumptions } \\
\text { and the basis for your } \\
\text { calculations. } \\
\text { If appropriate, use HYSYS } \\
\text { for your calculations. }\end{array}$ \\
\hline $\begin{array}{l}5.4 \text { Heat } \\
\text { Exchanger } \\
\text { Network }\end{array}$ & 20 & $\begin{array}{l}\text { Identify the heat duty of } \\
\text { each heat exchanger and } \\
\text { use the Pinch method to: } \\
\text { 1) determine the } \\
\text { minimum } \\
\text { utility } \\
\text { requirements of } \\
\text { your process, } \\
\text { and } \\
\text { 2) } \\
\text { propose a heat } \\
\text { integration } \\
\text { scheme. }\end{array}$ \\
\hline $\begin{array}{l}5.4 \text { Update } \\
\text { PFD and } \\
\text { Mass } \\
\text { Balances }\end{array}$ & 20 & $\begin{array}{l}\text { Update your mass } \\
\text { balances, PFD and stream } \\
\text { summary table to reflect } \\
\text { the results of this } \\
\text { milestone. }\end{array}$ \\
\hline $\begin{array}{l}5.5 \\
\text { Equipment } \\
\text { Table }\end{array}$ & 10 & $\begin{array}{l}\text { Thinking ahead... } \\
\text { Develop the equipment } \\
\text { summary table and include } \\
\text { the key parameters } \\
\text { required to size and cost } \\
\text { each piece of process } \\
\text { equipment. Fill in the } \\
\text { parameter values that you } \\
\text { already have. The balance } \\
\text { of the information will be } \\
\text { determined in the next } \\
\text { milestone. Sizing } \\
\text { calculations are not } \\
\text { required at this point. }\end{array}$ \\
\hline Total: & 100 & \\
\hline
\end{tabular}

\subsection{Final Report}

The final report of each group gets assembled progressively by completing each milestone. Each written submission is a compilation of the sections of the final report that have been written to date. It includes a new section summarizing the work completed over the last three weeks along with the sections that were previously submitted and recently updated using co-mentor feedback. Each design group is responsible for streamlining their design report as design changes are made and new sections are added. A copy of the final report is given to the client and also filed in the University library. 


\subsection{Teamwork}

To complete the requirements of each milestone on time, team members must learn to work effectively together. The team leader is responsible for coordinating meetings, issuing the minutes of the meetings with comentors and monitoring work progress. Members of the team take turns acting as team leader. The selection of a new leader normally takes place at the beginning of each new milestone.

The students are asked to evaluate each of their teammates after the first four milestones and at the end of the course. The evaluations are used in determining the final grade of each student as explained in Section 2.8.

\subsection{Client Meetings}

The faculty co-mentors arrange meetings with the assigned industrial client at the times indicated in Table 3. The first meeting normally takes place at the client's factory and includes a plant tour to get a better understanding of the problem. Subsequent meetings take place at UNB and are design review meetings which include the members of the design group, the co-mentors and the client. Design review meetings start with an oral presentation by the students and conclude with questions and feedback from the client and co-mentors. All group members are expected to participate in the oral presentations associated with the client meetings.

\subsection{Student Evaluation}

The breakdown of the final grade of the students is provided in Table 5. The final report has the largest weighting because it is the main product of the design exercise and the only document given to the client. Students receive their group mark for the milestones but are individually evaluated during the presentations and are assigned an individual mark for the final report. The individual mark for the final report is derived from the teammate evaluations and the average mark assigned to the team's final report by the co-mentors and course coordinators.

\section{RESULTS AND DISCUSSION}

In our experience, design is best taught by guiding students through the solution of a practical problem rather than engaging them in a loosely supervised design exercise. The milestones used in $\mathrm{ChE} 4225$ are an effective management tool for coordinating the efforts of students and co-mentors. The milestones define the tasks that must be completed by all teams and provide a common marking scheme for the co-mentors. This
Table 5: Breakdown of final grade

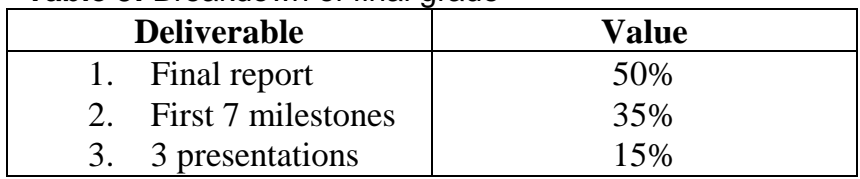

reduces variability in the expectations and requirements of co-mentors and ensures more uniformity in the quality of the projects. Over $74 \%$ of the students surveyed in 2013 agreed or strongly agreed that the milestones were clear, supported their design project and required an acceptable amount of work (Table 6). The vast majority of the comentors surveyed also agreed or strongly agreed that the milestones were clear and required an acceptable amount of work (Table 7).

The majority of the students and all co-mentors agreed or strongly agreed that having a milestone due every three weeks provided effective pacing of the students (Tables 6 and 7). The milestones and weekly meetings with comentors compel students to constantly work on their design project. The progress reports submitted by each team at the end of every milestone also allow co-mentors to comment on the details of the work that has been accomplished. The feedback is used to improve the design and polish the written submission. Further efficiencies are gained by asking students to format their written submissions as sections of the final report. In this manner, each submission is a new draft version of the final report. Design is however an iterative process and students must be reminded that they must continuously revise their draft report to reflect changes in their design. Streamlining of the draft report requires some rework but produces a final report of high quality. Reports from previous years which have been placed in the library also act as a quality benchmark that students try to achieve or exceed.

Engineering design is an art guided by techniques and strategies which is best learned by practicing design on a realistic project [5]. For this reason, we ask that the comentors be coaches and not supervisors. We want the students to be creative and not fearful of making mistakes. The milestones define the tasks that need to be completed and each team is free to decide how it will carry out the tasks. Co-mentors inform the students of their performance on the milestones when reviewing the written submissions. Each written submission is only worth 5\% of the overall mark (Table 5). The students are therefore not heavily penalized if they make mistakes while completing the tasks of the milestones. It is important however that they learn from their mistakes and incorporate the feedback provided by the co-mentors in their draft report in order to do well on the final report. The path followed by the students is not important if the client deliverables (final report and presentations) are of high quality. This is the reason why the weighting on the final report is so high. 
Table 6: Results of student survey conducted in April, 2013. Survey was completed by 23 of the 38 students registered in the course.

\begin{tabular}{|c|c|c|c|}
\hline \multirow[b]{2}{*}{ Statement } & \multicolumn{3}{|c|}{$\%$ of Responses } \\
\hline & $\begin{array}{c}\text { Strongly } \\
\text { disagree } \\
\& \\
\text { disagree }\end{array}$ & Neutral & $\begin{array}{l}\text { Agree \& } \\
\text { strongly } \\
\text { agree }\end{array}$ \\
\hline $\begin{array}{l}\text { 1. The milestones } \\
\text { supported the project } \\
\text { objective. }\end{array}$ & $22 \%$ & $4 \%$ & $74 \%$ \\
\hline $\begin{array}{l}\text { 2. The directives } \\
\text { associated with each } \\
\text { milestone were clear. }\end{array}$ & $9 \%$ & $9 \%$ & $82 \%$ \\
\hline $\begin{array}{l}\text { 3. The amount of work } \\
\text { required to complete each } \\
\text { milestone was acceptable. }\end{array}$ & $13 \%$ & $13 \%$ & $74 \%$ \\
\hline $\begin{array}{l}\text { 4. The frequency of the } \\
\text { milestones provided } \\
\text { effective pacing of our } \\
\text { work on the design project }\end{array}$ & $4 \%$ & $17 \%$ & $79 \%$ \\
\hline $\begin{array}{l}\text { 5. The mentoring model } \\
\text { used in the course is } \\
\text { effective. }\end{array}$ & $13 \%$ & $17 \%$ & $70 \%$ \\
\hline $\begin{array}{l}\text { 6. It was a motivating } \\
\text { experience to work on a } \\
\text { project sponsored by an } \\
\text { outside client. }\end{array}$ & & $4 \%$ & $96 \%$ \\
\hline $\begin{array}{l}\text { 7. The course was a } \\
\text { positive learning } \\
\text { experience. }\end{array}$ & $4 \%$ & $4 \%$ & $92 \%$ \\
\hline $\begin{array}{l}\text { 8. I feel that this course } \\
\text { has prepared me well for } \\
\text { my future career. }\end{array}$ & & $13 \%$ & $87 \%$ \\
\hline
\end{tabular}

Students in ChE 4225 are almost guaranteed to do well in the course if they work diligently and listen to feedback. Technical problems are rarely an issue in the course because extensive resources are available at UNB to help students find solutions to their technical issues. Ineffective teamwork is usually the main cause of poor student performance. To incite students to interact effectively with their peers, we let students choose their teammates and invite guest speakers to talk about team building at the start of the year. We also try to detect team problems early by monitoring team dynamics during the weekly mentor-student meetings and by asking students to evaluate their teammates at the end of the first semester. Tensions between team members normally buildup during the first semester and if they are not dissipated quickly, they can blow up early in the second semester. Members of ineffective teams have a poor experience in the course but hopefully learn a lesson that will benefit them in the future.
The teammate evaluations collected at the midpoint and at the end of the course are also useful for identifying students who are not doing their fair share of the work. Such students are penalized by our marking scheme and receive a lower mark on the final report (see section 2.8). We find that 'water-skiers' can more easily hide in large groups. This is the main reason why we limit the size of our teams to five members. Larger teams also have more difficulties scheduling meetings between themselves and with their co-mentors because of timetable conflicts.

Seventy percent of the students surveyed agreed or strongly agreed that the mentoring model used in the course is effective (Table 6). Our co-mentor model brings engineering practice in the classroom while keeping faculty members in control of the academic requirements. The strength of faculty members lies in engineering science and their knowledge of students' abilities. The role of faculty co-mentors is thus to ensure that students are being sufficiently challenged and are integrating knowledge and skills acquired in previous courses. Industrial co-mentors on the other hand ensure that best design practices used in industry are followed by the students and set the bar for the quality of the final reports. We aim to have all teams produce a final report of the quality expected from engineers working in industry. The assistance of practicing engineers in ChE 4225 has made the participation of faculty members in design activities less daunting and the number of faculty members involved in the course has increased from two in 2010-2011 to six in 2012-2013.

Table 7: Results of co-mentor survey conducted in April, 2013. Responses were received from 6 of the 9 comentors surveyed.

\begin{tabular}{|l|c|c|c|}
\hline \multirow{2}{*}{ Statement } & \multicolumn{2}{|c|}{ \% of Responses } \\
\cline { 2 - 4 } & $\begin{array}{l}\text { Strongly } \\
\text { disagree } \\
\text { \& } \\
\text { disagree }\end{array}$ & Neutral & $\begin{array}{c}\text { Agree \& } \\
\text { strongly } \\
\text { agree }\end{array}$ \\
\hline $\begin{array}{l}\text { 1. The instructions and } \\
\text { marking scheme } \\
\text { associated with each } \\
\text { milestone were clear. }\end{array}$ & $17 \%$ & & $83 \%$ \\
\hline $\begin{array}{l}\text { 2. The amount of work } \\
\text { required from the students } \\
\text { to complete each } \\
\text { milestone was acceptable. }\end{array}$ & & & $100 \%$ \\
\hline $\begin{array}{l}\text { 3. The frequency of the } \\
\text { milestones provided } \\
\text { effective pacing of the } \\
\text { students on the design } \\
\text { projects. }\end{array}$ & & & \\
\hline $\begin{array}{l}\text { 4. I feel that this course } \\
\text { has prepared the students } \\
\text { well for their future career. }\end{array}$ & & & \\
\hline
\end{tabular}


Nearly $100 \%$ of the students surveyed agreed or strongly agreed that it was a motivating experience to work on a project sponsored by an outside client (Table 6). The students are excited by the opportunity to work on a real industrial problem and want to impress the client, whom they view as a potential employer. The two teams assigned to each client work independently and thus the client is likely to get two innovative solutions to his/her problem. We clearly explain to the client however that we cannot guarantee the outcome of the project because it is an academic exercise designed to educate students. The performance of the students is generally excellent but not all students get an A in the course. This is the first reason why there is no fee for the design work performed by the students. The second reason is to avoid intellectual property issues. The students are the owners of the intellectual property that they develop but unless it is protected before the final presentation, it becomes public information.

The vast majority of students had a positive learning experience in the course (Table 6) and all co-mentors and $87 \%$ of the students surveyed either agreed or strongly agreed that the course prepares the students well for their future career (Tables 6 and 7). Written comments received from industrial co-mentors are also very encouraging:

"I believe this course and process to be one of the most valuable student learning experiences within the degree program... I enjoyed my co-mentor involvement completely."(L. Bulmer)

"It was encouraging to see the students grow through the term and perform well at the final presentations. I received positive feedback on the students' performance from the client after the presentations. Very effective final year course in my view!"

These positive results and comments confirm that our collaborative model for teaching $\mathrm{ChE} 4225$ is effective. The model is currently being deployed in other engineering programs at UNB with support from the NSERC-UNB Chair for Collaborative Engineering Design Education.

\section{CONCLUSIONS}

A collaborative approach has been successfully used to teach chemical process design to senior undergraduate students in the Chemical Engineering program at UNB since 2010. Teams consisting of four or five students, work on design projects sponsored by industry and are comentored by a practicing engineer and a faculty member. Eight evenly-spaced milestones are used efficaciously to guide and pace students and co-mentors. By working collaboratively with outside clients and practicing engineers, we have increased the number of faculty members interested in design activities, are producing engineering graduates who have greater confidence in their abilities, and are helping local companies obtain innovative design solutions.

\section{Acknowledgements}

Funding received from the Natural Sciences and Engineering Research Council of Canada for the NSERCUNB Chair for Collaborative Engineering Design Education is gratefully acknowledged. The authors are also grateful to the faculty and industrial co-mentors who have contributed to ChE 4225 between 2011 and 2013. We also acknowledge the many colleagues who have provided valuable feedback regarding the course.

\section{References}

[1] Richard Turton, Richard C. Bailie, Wallace B. Whiting, Joseph A. Shaeiwitz and Debangsu Bhattacharyya, Analysis, Synthesis, and Design of Chemical Processes. Upper Saddle River, NJ: Prentice Hall, 2012 ( $4^{\text {th }}$ edition), 1007 pp. \{ISBN: 978-0-13-261812-0\}

[2] H. Scott Fogler and Steven LeBlanc, Strategies for Creative Problem Solving. Upper Saddle River, NJ: Prentice Hall, 2008 ( $2^{\text {nd }}$ edition), 300 pp. \{ISBN: 978-0-13-008279-4 $\}$

[3] Gael D. Ulrich and Palligarnai T. Vasudevan, Chemical Engineering Process Design and Economics-A Practical Guide. Durham, NH:Process Publishing, 2004 ( $2^{\text {nd }}$ ed.), 706 pp. \{ISBN: 0-9708768-2-3\}

[4] Tom Brzustowski, "Canadian Engineers and Our Future Prosperity", presentation at the Engineering Summit (Montreal, PQ; 19 May 2009).

[5] George E. Dieter and Linda C. Schmidt, Engineering Design. New York, NY: McGraw-Hill, 2013 ( $5^{\text {th }}$ edition), 825 pp. \{ISBN: 978-0-07-339814-3\}

[6] Warren D. Seider, J.D. Seader, Daniel R. Lewin, and Soemantri Widagdo, Product and Process Design Principles: Synthesis, Analysis, and Evaluation. Hoboken, NJ: John Wiley \& Sons, 2009 ( $3^{\text {rd }}$ edition), 728 pp. \{ISBN: 978-0470-04895-5 \} 